\title{
福岡県竜円鉱山産閃ウラン鉱の産状と絶対年令
}

\section{Mode of ocurrence and absolute age of uraninite from Ryuen mine, Fukuoka Prefecture}

$$
\begin{aligned}
& \text { 井上秀 雄 (Hideo Inone) } \\
& \text { 佐 藤 和 郎 (Kazuo Sato) }
\end{aligned}
$$

\begin{abstract}
Abstrct: There are three pegmatites in Ryuen mine, Fukuoka Prefecture, which intruded in Masaki granite of the middle Cretaceous. The $\mathrm{U}-\mathrm{Pb}$ age of uraninite from a pegmatite has been chemically determined as $100 \times 10^{6}$ years by Kimura and Iimori (1937). Uraninite was collected from the other pegmatite, of which mode of occurrence was different from the above mentioned uraninite. It occurred in chlorite vein cut the pegmatite. In order to know whether or not any measurable time interval existed between the pegmatite solodification and the vein formation, isotopic $\mathrm{U}-\mathrm{Pb}$ age was determined on the uraninite from the chlorite vein. The age of uraninite is $110 \times 10^{6}$ years and the formation of chlorite vein continued immediately after the solidification of pegmatite.
\end{abstract}

\section{1. ま え がき}

羙山鉱山は福岡罧田川郡真崎にあり，古くからペグマタイト鉱床として稼行されまた

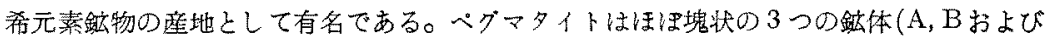
C)加らなりここの中Aの間ウラン鈗については木村，飯盛”によりウラン一鉛法による 年令決定肪行われている。最近Cにおいて上記のものと産状を異にする畹ウラン鋶を発

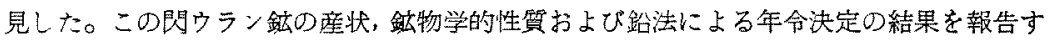
る。

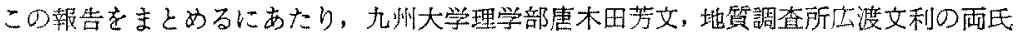
に種々の助言を得た。こつに㳭く感謝する。

\section{2. 地質 概 要}

北九州の花崗岩類は冨田達，唐木田芳文等2）によれば，古期および新期の 2 つに大別 されこれを古い方から記載すると次のようになる。

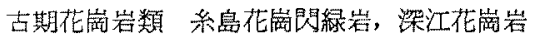

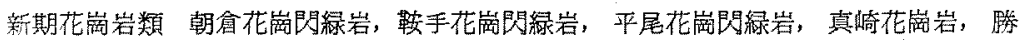
山花菵岩, 嘉穂花崗岩, 早良花崗岩, 佐賀花崗岩

これらの花崗岩類中，古期のものの迸入時期は明らかでないが，新期のもののうち鞍

* 地望調查所銥床部

** 東京大学理学部化学教空・東京大学地震研究所 


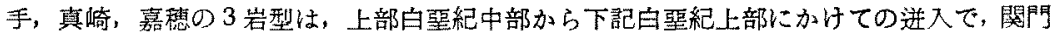

層群の堆積後とされている。

鉝山および周辺の地質は田川変成岩類とこれを貫く花崗岩類ここれらを不整合に被う第

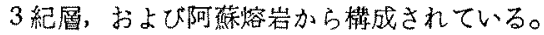

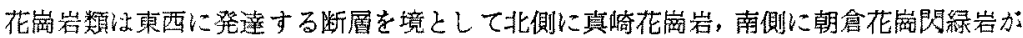
分布している。前者は粗粒の黒雲母花峝岩で後者を貫き，多くのヘグマタイトを伴う。ま た後渚は一般に塊状で花崩閃緑岩貲である。

第 3紀層は始新世の福岡畨群からなり，鍍山の東側およぴ西溉に分布している。

\section{3. 閃ウラン鉱の産状および外観}

第 1 図 福岡罢竟门鉣山附近の地筫図

(稻井・広渡原図)

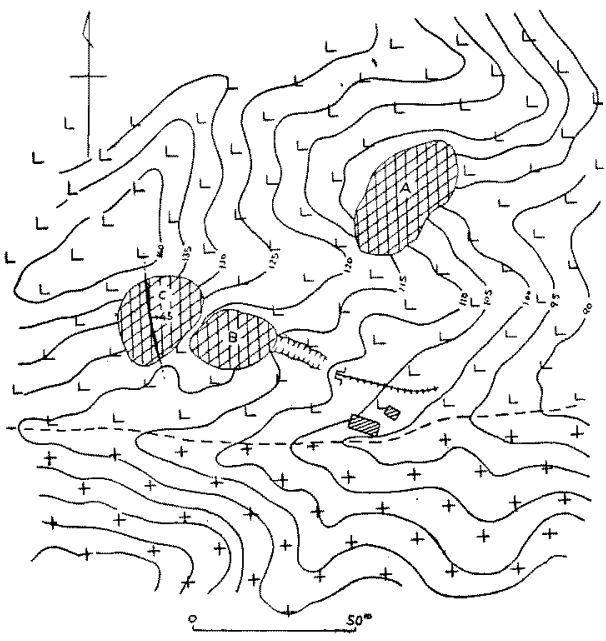

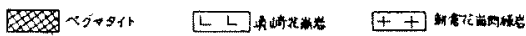

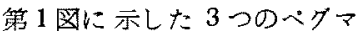
タイト鉝体は，いゔれも面径 20 $\sim 30 \mathrm{~m}$ 前後で塊状を呈する。一 般に钩体の中心部は石英を主と し，外款部は長石からなり，ほ く同心円状の罢带構造をなして いる。

長島乙志，木村”に上り発見 され，木村，飯盛により年令决 定が行われた閃ウラン鉱は，A 鈗体の長石を主とする部分に産 するが，今回発見した閃ウラン 鉉は，C鉱体を $\mathrm{N} 70^{\circ} \mathrm{W} に$ に切る 方り面にそつた眽状部に見出だ された。この脈状部は緑泥石， 腪水鉛鉣，黄銅鈆よりなる。

迈り面の規模は延長的 $8 \mathrm{~m}$ を 有する。

閃ウラン鈆は肉眼的に諗めら れ，黒色で光沢が強い。大きさ は径 $0.5 \sim 1.0 \mathrm{~mm}$ ，立方体結晶であり，つねに長石および葉片状の緑泥石中に濃集する。

\section{4. 閃ウラン鉱の鉣物学的性算}

（1）反射顕微鏡下の性質 第 2 図に示すように主として単結晶として産出するが，と きにはこれらの単結晶が集合して産出する。光学的には等方性で，反射色は磁鉄鉱より暗 く，淡褐灰色を呈する。研磿面には網目状の割れ目が䁰著に発達している。

閃ウラン鉣に密接な随伴関保を有する鉣物は黄鉄鉣と鋭錐石で，前者は閃ウラン鉣をと り囲むように産出し，愿さ $25 〜 50 \mu$ を有する。後者は大部分畉ウラン銥の中，または周 辺の艮石あるいは粶泥石中認められる。 
第 2 図福岡県竜円鉱山産閃ウラン鉱の産状
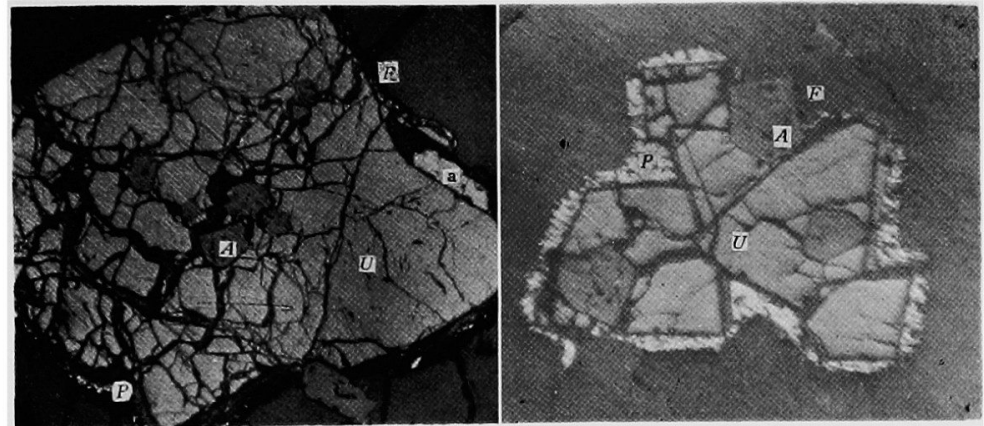

$\times 10$

$\mathrm{U} ：$ 閃ウラン鉱

A : 鋭錐石

F： 長石

$\mathrm{P}$ ： 黄鉄鉱

a：未決定鉱物

研磨面の試薬テストの結果， 反応は全く認 第 1 表 閃ウラン鉱の $\mathrm{X}$ 線回折値 められなかつた。使用した試薬は次のとおり である。 $\mathrm{KCN}, \mathrm{KOH}, \mathrm{HCl}, \mathrm{HgCl}_{2}, \mathrm{FeCl}_{3}$, $\mathrm{KMnO}_{4}+\mathrm{H}_{2} \mathrm{SO}_{4}, \mathrm{KMnO}_{4}+\mathrm{KOH}$.

(2) X 線粉末回折試験 アイソダイナミッ クセパレーターを使用し，絕粋な閃ウラン鉣 を分離採取してX線粉末試験の試料とした。 第 1 表にこの結果を示す。

(3) $T_{\alpha}$ の測定 $T_{\alpha}$ の測定を, 顕徽鏡下 で閃ウラン鉱と同定した試料について試み,

\begin{tabular}{l|r|r}
\hline $\mathrm{d}$ & $\mathrm{I}_{\mathbf{0}}$ & $\mathrm{dhkl}$ \\
\hline $3.17 \AA$ & 100 & 111 \\
2.74 & 40 & 002 \\
1.93 & 50 & 122 \\
1.653 & 45 & 113 \\
1.580 & 12 & 222 \\
1.370 & 10 & 004 \\
1.255 & 16 & 133 \\
1.224 & 15 & 024 \\
\hline
\end{tabular}

$\mathrm{Cu} \mathrm{K}_{\alpha}$, Ni filter, 次の值を得た。（No.1 210,No.2 229, No.3 222) この中 3 個の閃ウラン鉱と比較の ため, フランス産㗏青ウラン鉱を実験に供した。乾板は ET-2E を使用した。

フランス，ボア，ノアール鉱山産瀝青ウラン鉱の T $\alpha$ は 174 である。

閃ウラン鉱は一般に $\mathrm{T}_{\alpha}=160$ - $215^{3)}$ であり，上記の結果はこの範囲を若千上まわる值 であるが, 露出時間, $\alpha$ 飛跡を数える面積のとり方による誤差によるものと考えられる。 すなわち， $\mathrm{T}_{\alpha}$ の測定からも閃ウラン鉣であることが同定される。

\section{4. 閃ウラン鉱の年令決定}

鈸物学的に純粋に分離した閃ウラン鉣細粉を分析試料とし，(1) $0.22820 \mathrm{~g}$ を鈆の抽出， 同位体分析およびウランの定量に使用し，(2) $0.09367 \mathrm{~g}$ を鉛の定量に供した。いずれも $6 \mathrm{~N}$ の硝酸で分解したが，(2)に対しては分解処理後ただちに $3.07 \mathrm{mg}$ の鉛を spikeし て加えた。

（1）鉛の同位体分析 通常の方法で鉛を分離し，精製して約 $0.8 \mathrm{mg}$ のヨウ化跺とし， テトラメチル鉛法4)によりその同位体存在比を測定した。1 回の測定に使用できる鈆の 
量が少いので，第2表に見られるごとく， ${ }^{204} \mathrm{~Pb}$ の存在度はその上限のみが得られた。

（2）ウランの定量 通常の方泆により $\mathrm{U}_{3} \mathrm{O}_{8}$ として重量を測つた。ウラン酸アンモ ニウム沈でんを濾别した溶液について回収操作を行い,この部分にウランが存在しない ことを確めた。

(3) 同位体茶秎法による鉛の定量（1）上同一の方法によりヨウ化鉛を分離し，テトラ メチル鉛として同位体分析を行つた。（1）により得られた瓦ウラン鈗の鉛の同位体存在比 および閃ウラン鉱の鉛と既知量の spike の鈆の混合物の同位体存在比汃ら計算し，試料 中の錎の濃度を求めた。

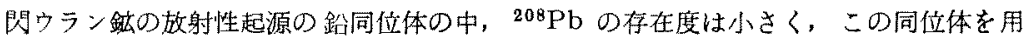

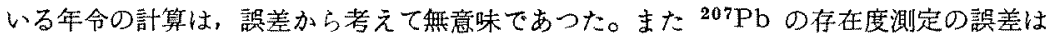
${ }^{207} \mathrm{~Pb} /{ }^{206} \mathrm{~Pb}$ 一年令を計算するためにには大きすきた。表にみられるとおり，残りの 2 種

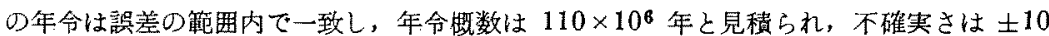
$\times 10^{6}$ 年以内と考えられる。

第 2 表 閃ウラン鉱の分析結果と年令 鈆の同位体存在比 (鿌子数百分率)

\begin{tabular}{|c|c|c|c|c|c|}
\hline 䝷量分析試料 & & ${ }^{204} \mathrm{~Pb}$ & ${ }^{206} \mathrm{~Pb}$ & ${ }^{207} \mathrm{~Pb}$ & ${ }^{208} \mathrm{~Pb}$ \\
\hline 閃ウラン鉱 & 1 & $<0.1$ & $91.07 \pm 0.71$ & $4.94 \pm 0.17$ & $3.82 \pm 0.19$ \\
\hline$"$ & $\|$ & $<0.1$ & $91.85 \pm 0.30$ & $4.75 \pm 0.14$ & $3.42 \pm 0.11$ \\
\hline Spike の鈆 & & $1.364 \pm 0.002$ & $24.93 \pm 0.05$ & $21.38 \pm 0.04$ & $52.33 \pm 0.20$ \\
\hline 閃ウラン鉣+spike & 1 & $1.068 \pm 0.029$ & $40.92 \pm 0.16$ & $17.39 \pm 0.23$ & $40.63 \pm 0.37$ \\
\hline " & $\llbracket$ & $1.131 \pm 0.018$ & $41.14 \pm 0.28$ & $17.24 \pm 0.46$ & $40.49 \pm 0.60$ \\
\hline
\end{tabular}

ウランおよび鈆の同位体含有量 (mg./g.)

\begin{tabular}{|c|c|c|c|}
\hline $\mathrm{U}: 639.6$ & $\mathrm{~Pb}:(10.45 \pm 0.24)$ & & \\
\hline${ }^{238} \mathrm{U} 635.0 *$ & ${ }^{207} \mathrm{~Pb}$ (故射性 & & $9.47 \pm 0.37 * *$ \\
\hline 4.61 & ${ }^{207} \mathrm{~Pb}$ & ) & $0.431 \pm 0.097$ \\
\hline
\end{tabular}

閃ウラン鉣の年命*（単位：106 年)

\begin{tabular}{cc}
\hline${ }^{206} \mathrm{~Pb} /{ }^{23}{ }^{2} \mathrm{U}$-年令 & ${ }^{207} \mathrm{~Pb} /{ }^{235} \mathrm{U}$-年命 \\
$111 \pm 5$ & $104 \pm 23$ \\
\hline
\end{tabular}

[注] * 現在のウランの同位体存在比として $\left[{ }^{238} \mathrm{U}\right] /\left[{ }^{235} \mathrm{U}\right]=137.8$ (Inghram, 1946 ${ }^{6)}$ を用いた。 また壊変定数として ${ }^{238} \mathrm{U}: \lambda=1,54 \times 10^{-10} \cdot \mathrm{y}^{-1}$ (Kovarik and Adams, 1955) ${ }^{7}$, ${ }^{235} \mathrm{U}: \lambda=9.72 \times 10^{-10} . \quad \mathrm{y}^{-1}$ (Fleming, Ghiorso and Cunningham, 1952) ${ }^{8)}$ を用いた.

** 非放射性起源の釭(original common lead)の同位体存在比として ${ }^{204} \mathrm{~Pb}$ $=1.355 \%,{ }^{106} \mathrm{~Pb}=25.05 \%,{ }^{207} \mathrm{~Pb}=21.13 \%,{ }^{208} \mathrm{~Pb}=52.46 \%$ を仮

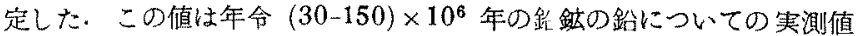
の籁囲内にある゙ 


\section{6. 年令值について}

竜円鍍山の3つのヘグマタイト鉱体の中，A鉱体の年令はその聞ウラン鉱についての木 村，飯盛の測定によれば $96 \times 10^{6}$ 年であった。今回発見された略ウラン鉣はC 鉣体の之 り面に発達した緑泥石搌中にあり，その年令は $(110 \pm 10) \times 10^{6}$ 年である。除法による

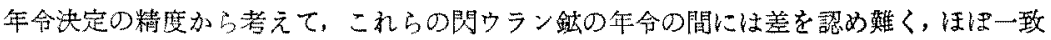
するといえる。したがつて緑泥石脈はぺグマタイト鍼体の晶出直後に生成したものと推 定して差支えないと考えられる。なお，この閃方ン鉱を伴うべタマタイト（およで真㥓 花菵岩) の絶詨年合も $(110 \pm 10) \times 10^{6}$ 年で, 上部白惡紀に相当する。

\section{引用文 献}

1) 木村健二郎，飯盛武夫，日化， 58，1135～1143，1937.

2)壹田 達, 虐木由管文, 私信による。

3) Yagoda, H., Radioactive measurements with nuclear emulsions, Johr Wiley, N. Y, 1949.

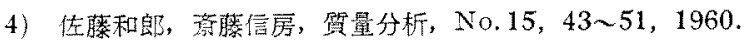

5) Collins, C. B., Russell, R. D. and Farquhar, R. M. Canad. J. physics, $31,402 \sim 418,1953$.

6) Inghram, M.G., Manhattan Project Technical Series, Div. 2, Gaseous Diffusion Project, 14, V, 35, 1946.

7) Kovarik, A.F. and Adams, N.I., Phys. Rev., 98, 46, 1955.

8) Fleming.E.H., Ghiorso A. and Cunningham, Phys. Rev, 88, 642 652, 1952 .

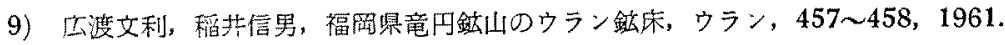

